\title{
A contribuição de todos para 0 objetivo comum
}

Carlo Milani'

A riqueza e a respeitabilidade de um Serviço Médico são a sua capacidade de ter uma produção científica, seja esta sob forma de livros, artigos em revistas especializadas ou apresentação de trabalhos em congressos. Felizmente, todos os integrantes da nossa disciplina têm desenvolvido uma atividade científica invejável.

Esta coletânea de artigos versa sobre quase todas as subespecialidades da Ortopedia e da Traumatologia, expondo uma casuística expressiva de pacientes provenientes dos hospitais da Faculdade de Medicina do ABC.

Agradeço a todos os autores e coautores que colaboraram com esta revista, entendendo bem a mensagem que, inclusive, está nas diretrizes da CAPES, ou seja, a de publicar nossa experiência com as várias entidades nosológicas da nossa especialidade, mostrando, com isso, a maturidade do nosso Serviço, bem como a revista Arquivos Brasileiros de Ciências da Saúde pela oportunidade da contribuição a este importante veículo de comunicação científica.

Eis a contribuição da disciplina de Ortopedia e Traumatologia aos nossos pares. Boa leitura. 